\title{
Morphoregression and length-weight relationship of Bali sardinella, Sardinella lemuru Bleeker 1853 in Bali Strait Waters
}

\author{
[Morforegresi dan hubungan panjang bobot ikan lemuru, Sardinella lemuru Bleeker 1853 di \\ perairan Selat Bali]
}

\author{
Nyoman Dati Pertami ${ }^{1,2 \bowtie}$, M.F. Rahardjo ${ }^{3}$, Ario Damar ${ }^{3}$, I.W. Nurjaya ${ }^{4}$ \\ ${ }^{1}$ Graduate School of Doctoral Programs, Bogor Agricultural University \\ ${ }^{2}$ Faculty of Marine Sciences and Fishery Udayana University \\ Campus Bukit Jimbaran Street Udayana University, Badung - Bali 80361 \\ ${ }^{3}$ Department of Aquatic Resources Management \\ ${ }^{4}$ Department of Marine Technology \\ Faculty of Fisheries and Marine Sciences, Bogor Agricultural University \\ Campus IPB Dramaga, Agatis street, Bogor 16680
}

Received: 22 August 2018; Accepted: 16 October 2018

\begin{abstract}
Bali Sardinella, Sardinella lemuru Bleeker 1853, included in small pelagic groups which have an important economic value. The production of Bali Sardinella was the highest among the other small pelagic fish in Bali Strait waters. The morphoregression and length-weight relationship are important to be known to facilitate the conversion between a length measurement to another type of length measurement and the weight. The aims of this research were to reveal the relationship between total length (TL) and standard length (SL), total length and fork length (FL), fork length and standard length, and the length-weight. The research was held in Bali Strait waters from March 2017 - Mei 2018. The morphoregression was analyzed using simple linear regression, whereas the length-weight relationship using power regression. A total of 470 individuals of Bali sardinella were collected during the study period. The fish that analyzed have a length range $9.7-20.2 \mathrm{~cm}$ TL. The average length of Bali sardinella was $13.7 \mathrm{~cm}$. The relationship between total length (TL) and standard length (SL); total length (TL) and fork length (FL); fork length (FL) and standard length (SL) for Bali sardinella respectively were $\mathrm{TL}=1.1038 \mathrm{SL}+0.9313$; $\mathrm{TL}=1.0861 \mathrm{FL}+0.2967$; and $\mathrm{FL}=1.0068 \mathrm{SL}+$ 0.6936 , respectively. The value of $b$ which were generated from the length-weight relationship of Bali Sardinella was 3.22 with the growth patterns were positive allometric.
\end{abstract}

Keywords: Bali Strait, morphoregression, length-weight relationship, Sardinella lemuru

\begin{abstract}
Abstrak
Ikan lemuru, Sardinella lemuru Bleeker 1853, termasuk dalam kelompok ikan pelagis kecil yang bernilai ekonomis tinggi. Dibandingkan dengan jenis pelagis kecil lainnya, hasil tangkapan ikan lemuru lebih dominan di perairan Selat Bali. Persamaan morforegresi dan hubungan panjang bobot penting untuk diketahui sehingga mudah melakukan konversi dari satu jenis panjang ke jenis panjang lain dan bobotnya. Penelitian ini bertujuan untuk mengungkap hubungan antara panjang total (PT) dengan panjang baku (PB), panjang total dengan panjang cagak (PC), panjang cagak dengan panjang baku, serta hubungan panjang bobot ikan lemuru. Penelitian dilaksanakan di perairan Selat Bali kurun waktu Maret 2017 - Mei 2018. Morforegresi dianalisis menggunakan regresi linear sederhana, sedangkan hubungan panjang bobot dianalisis menggunakan regresi power. Ikan lemuru (Sardinella lemuru Bleeker 1853) yang dikumpulkan selama penelitian berjumlah 470 ekor. Ikan yang dianalisis memiliki kisaran panjang antara 9,7-20,2 cm PT. Panjang rata-rata ikan lemuru adalah $13,7 \mathrm{~cm}$. Hubungan antara panjang total (PT) dan panjang baku (PB); panjang total (PT) dan panjang cagak (PC); panjang cagak (PC) dan panjang baku $(\mathrm{PB})$ ikan lemuru secara berturut-turut adalah $\mathrm{PT}=1,1038 \mathrm{~PB}+$ 0,9313; $\mathrm{PT}=1,0861 \mathrm{PC}+0,2967$; and $\mathrm{PC}=1,0068 \mathrm{~PB}+0,6936$. Nilai $\mathrm{b}$ yang terbentuk pada hubungan panjang bobot ikan lemuru adalah 3,22 dengan pola pertumbuhan adalah allometrik positif.
\end{abstract}

Kata penting: hubungan panjang-bobot, morforegresi, ikan lemuru, Selat Bali

\section{Introduction}

Fish is an important source of nutrients such as a protein, Omega-3 with vitamins and minerals. Due to the higher components made

$\triangle$ Correspondence author

E-mail address:dati_pertami@yahoo.co.id fish as an alternative source of protein than other sources of meat (Sikoki \& Otobotekere 1999, Mahrus et al. 2012). Marine fish is more abundant when compared with freshwater fish, which is relatively cheap in Indonesia. Clupeidae families are known as marine fish that contains a high 
amount of mineral and spread in the eastern Indian Ocean including Bali Strait. Clupeidae families in Bali strait waters include Bali Sardinella or lemuru fish (Sardinella lemuru Bleeker 1853) and goldstripe sardinella or tamban (Sardinella gibbosa) (Pertami et al. 2017). Sardinella lemuru is included in the group small pelagic fish. Small pelagic fish have an important ecological role in food webs and become the main food source in the sea (Pedrosa-Gerasmio et al. 2015).

Lemuru is an important economic fish in Bali Strait waters (Merta 1992). Lemuru fishing activity is increasing year by year. The excessive use of fish resources, especially lemuru in Bali Strait waters, will have an adverse impact on the ecosystem. Impacts that occur can cause changes in abundance, productivity, and community structure including catches, changes in species dominance, and size spectra. Currently, the productivity of lemuru is decreasing, even predicted to begin to disappear (Merta 1992, Tinungki 2005, Djamali 2007, Wujdi et al. 2012). Research related to Sardinella lemuru in Bali Strait waters (Merta, 1992, Tinungki 2005, Djamali 2007, Buchary 2010, Sartimbul et al. 2010, Purwaningsih et al. 2011, Simbolon et al. 2011, Purwaningsih 2015, Prasetyo \& Purwoko, 2016) and other territorial (Gaughan \& Mitchell 2000, Mahrus et al. 2012, Willette \& Santos 2013, Luceño et al. 2014) have been widely carried out.

The study of the length-weight relationship in fishes by fishery management system has been mainly directed toward two objectives, namely, to provide basic information of average population in certain long groups (Beyer 1987) and examine the relative value of fish (Bolger $\&$ Connoly 1989). Statistical analysis is indispensable in analyzing and evaluating relationships between several types of fish. Morphoregression equation and length-weight relationship are important to know so that it is easy to convert from one type of length to another type of length and weight. This study aims to reveal the relationship between total length (TL) and standard length (SL), total length and fork length (FL), fork length and standard length, and the length-weight of Bali sardinella (Sardinella lemuru Bleeker 1853).

\section{Materials and method}

The study was conducted from March 2017 - May 2018. Sampling was carried out 2 days in each month. Fish samples were obtained in the coastal of Bali Strait waters from Pengambengan (Jembrana Regency) in three locations with different characteristics of marine environment (Figure 1). The collection of Bali Sardinella (Sardinella lemuru Bleeker 1853) in the coast of Bali Strait waters was carried out using fishing boats in three fishing grounds. Fishermen in fishing activities use gillnet (mesh size 2-2.25 inches) and fishing rods. In addition, fish samples were also obtained by combing purse seine fisherman who landed caught fish in Pengambengan Fishing Port.

The measuring growth parameters such as total length (TL), standard length (SL), and fork length (FL), using a fish measuring board with an accuracy level of $0.1 \mathrm{~cm}$. Fish weight is weighed using a scale with an accuracy of $0.1 \mathrm{~g}$.

The calculation of length-weight relationship Bali Sardinella refers to the equation (Ricker 1970):

$$
\mathrm{W}=\mathrm{aL}^{\mathrm{b}}
$$

Where: $\mathrm{W}=$ weight of fish (gram), $\mathrm{L}=$ total length of fish $(\mathrm{mm})$, $a$ and $b=$ constants

Morphoregression analysis was performed using simple linear regression, while the lengthweight relationship was analyzed using power regression. The t-test was conducted to test the 
value of b. Effendie (2002) states that there were three possible values of $b$ that appear in the calculation of the length-weight relationship of fish, namely $b<3, b=3$ and $b>3$. The value of $b<3$ indicates that the weight was not faster than the length, $b=3$ means the length and weight of fish in a balanced condition, whereas the growth of fish length was slower than the weight gain the value was $b>3$.

\section{Result}

Total of samples collected during the research was 470 individuals (Sardinella lemuru Bleeker 1853) consists of 122 females, 162 males and 186 individuals were unsexed, were collected from Bali Strait. Total length of fish ranged $9.7-20.2 \mathrm{~cm}$, whereas the average was $13.7 \mathrm{~cm}$ (Figure 2).

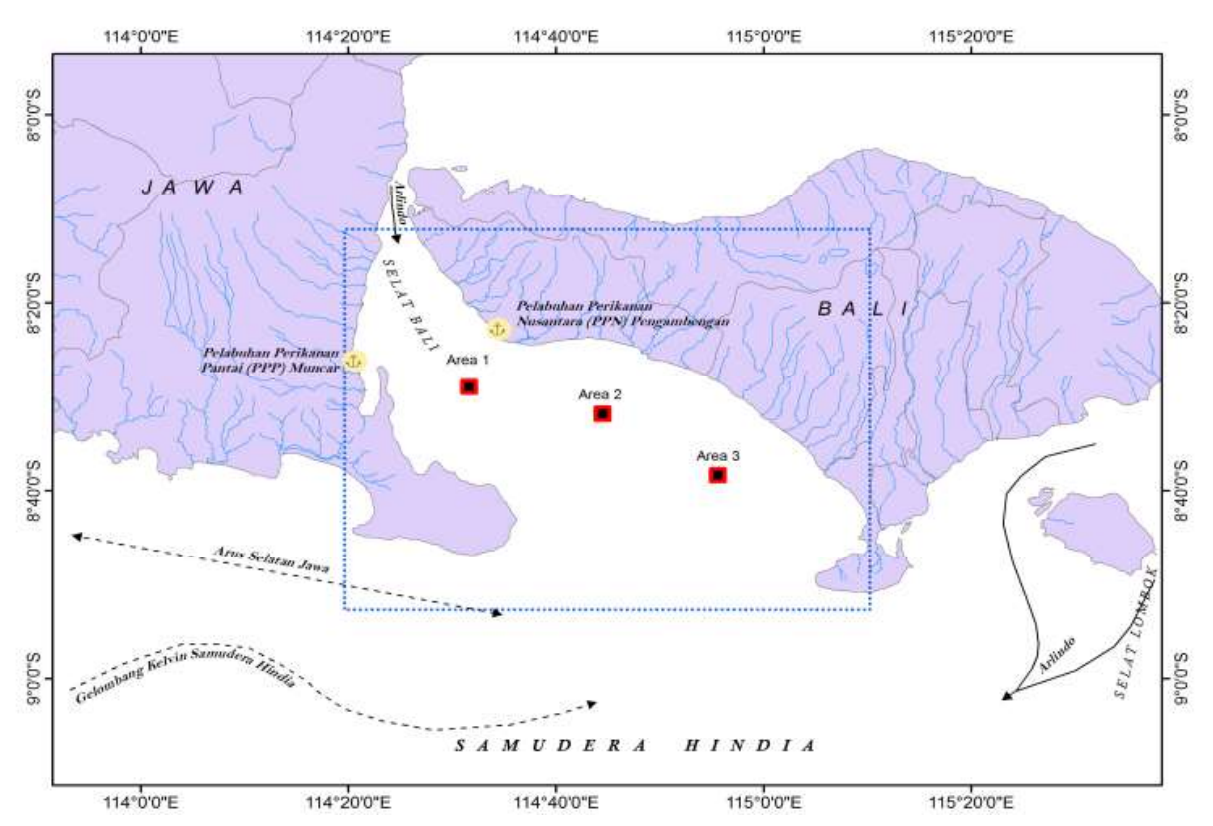

Figure 1. Sampling location of Bali Sardinella in the coast of Bali Strait waters (1, 2, 3 are fish sampling areas). Source: Pertami et al. 2017.

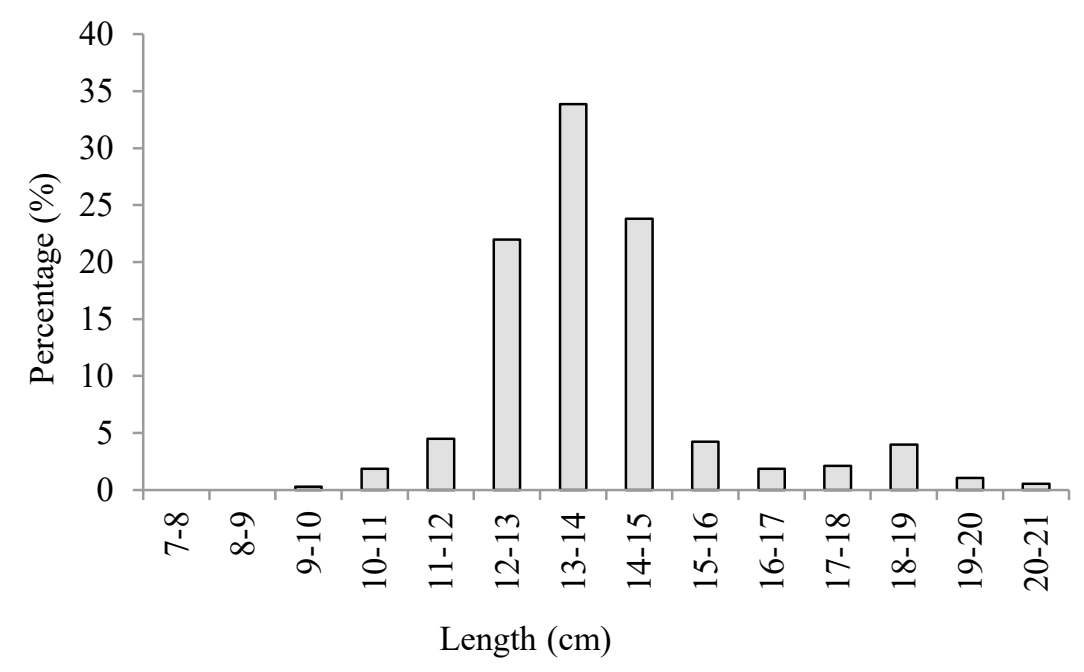

Figure 2. Length range of Bali Sardinella in Bali Strait Waters $(\mathrm{N}=470)$. 
According to the samples, the body size of Bali sardinella caught during the research was diverse. According Merta (1992), there are four groups of Bali sardinella, namely sempenit (size $<11 \mathrm{~cm}$ ); protolan (sizes range from 11-15 cm); lemuru (size 15-18 cm), and lemuru kucing (size $>18 \mathrm{~cm}$ ). Based on research, the dominant group caught was "protolan" of 382 individuals. The second dominant group was "lemuru" of 56 individuals, followed by "lemuru kucing" of 21 individuals and "sempenit" of 11 individuals. The size composition of Bali Sardinella groups in the Bali Strait waters is shown in Table 1.

Weight and length of Bali Sardinella have a strong relationship. This can be seen from the correlation coefficient (r) of Bali Sardinella that is close to 1 (Figure 3). After t-test was carried out on the b-value of length-weight relationship, it was found that Bali Sardinella growth pattern was a positive allometric (Fig. 3). Length-weight equation Bali Sardinella generated in this research was $\mathrm{W}=0.0046 \mathrm{~L}^{3.2205}$.

Based on figure 4 , the correlation value of total length and standard length Bali sardinella in Bali Strait waters was positive. By each standard length increased, also accompanied by a total length increase. Based on determination coefficient value $\left(\mathrm{R}^{2}\right)$, it is known that standard length can be used to estimate the total length. The relationship between TL and SL for Bali sardinella was $\mathrm{TL}=1.1038 \mathrm{SL}+0.9313$.

Table 1. Composition of Bali sardinella size groups in the Bali Strait Waters

\begin{tabular}{lcc}
\hline & Fish size group & amount \\
\hline Sempenit $(<11 \mathrm{~cm})$ & 11 \\
Protolan $(11-15 \mathrm{~cm})$ & 382 \\
Lemuru $(15-18 \mathrm{~cm})$ & 56 \\
Lemuru kucing $(>18 \mathrm{~cm})$ & 21 \\
Total & 470 \\
\hline
\end{tabular}

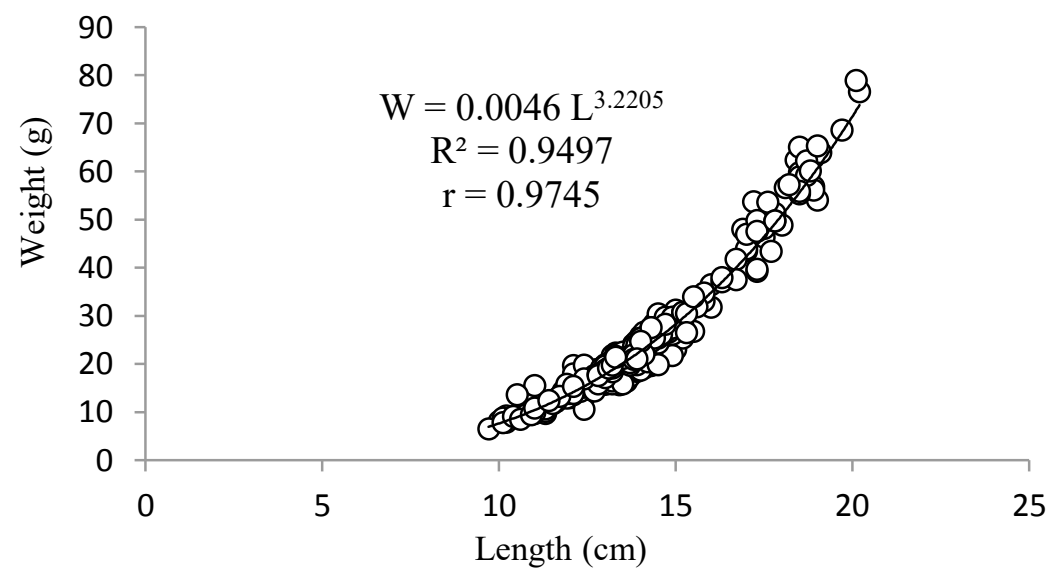

Figure 3. Length-Weight Relationship of Bali Sardinella in Bali Strait waters $(N=470)$ 


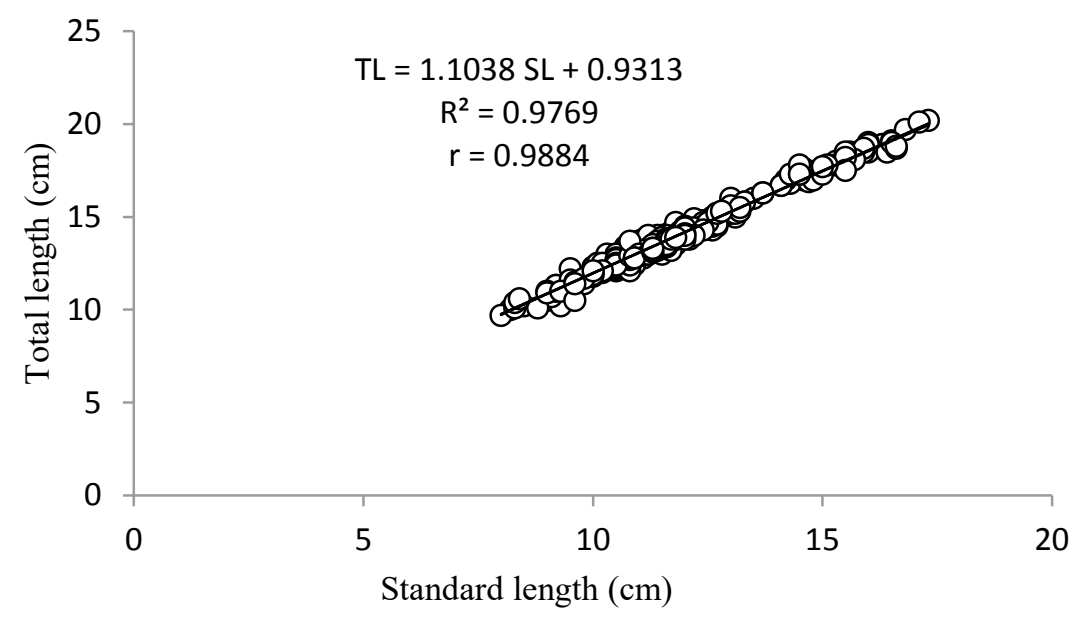

Figure 4. Relationship of standard length and total length of Bali sardinella in Bali Strait waters $(N=470)$

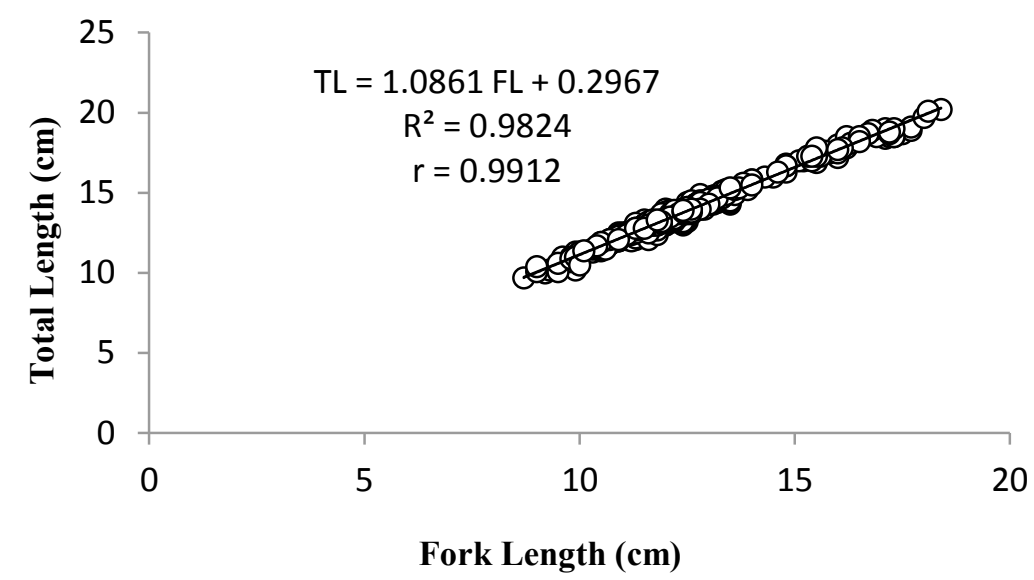

Figure 5. Relationship of fork length (FL) and total length (TL) Bali sardinella in Bali Strait waters $(\mathrm{N}=$ 470)

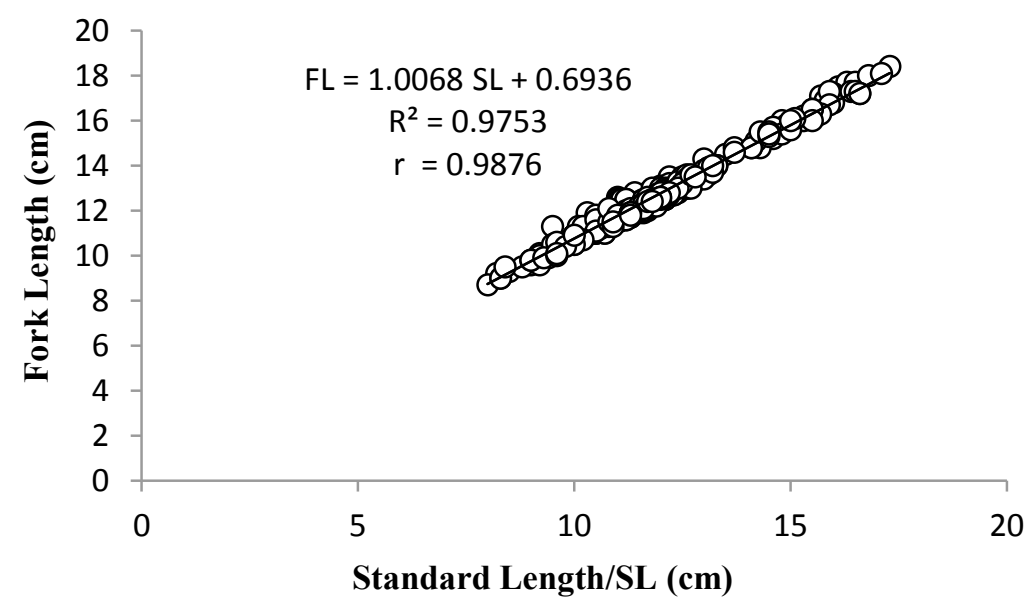

Figure 6. Relationship of standard length (SL) and fork length (FL) of Bali sardinella in Bali Strait waters $(\mathrm{N}=470)$ 
Fork length (FL) can be used to estimate the total length (TL) of Bali sardinella, by the equation of $\mathrm{TL}=1.0861 \mathrm{SL}+0.2967$ (Figure 5). The relationship between standard length (SL) and total length (TL) has a high correlation value $(r=1)$. Similarly, the correlation values of fork length (FL) and total length (TL) relationship was high.

Standard length, in addition to being used to estimate the total length, also can be used to predict fork length (fig. 6). This known from the coefficient of determination $\left(\mathrm{R}^{2}\right)$ and the correlation coefficient (r) which is formed from the regression equation between standard length and fork length for the type of fish observed. Relationship of standard length (SL) and fork length (FL) was FL $=1.0068 \mathrm{SL}+0.6936$.

\section{Discussion}

The average length of Bali Sardinella (Sardinella lemuru Bleeker 1853) is $13.7 \mathrm{~cm}$. The overall population of lemuru fish (Sardinella lemuru Blk.) in the east coast waters of Siberut Island has an average length of $16.8 \pm 0.14 \mathrm{~cm}$ with the smallest size of $12.0 \mathrm{~cm}$ and the largest size of $21.4 \mathrm{~cm}$ (Ginanjar 2006). Froese \& Pauly (2018) stated that Sardinella lemuru has a maxi- mum length of $23.0 \mathrm{~cm}$ (SL male), and mostly in $20 \mathrm{~cm}(\mathrm{SL})$.

Information on the length-length relationship of Bali sardinella is insufficient. Necessarily, it is important to have the information to render the result more reliable when making comparisons between studies which used different type of length measurement. This research is the first study which analyzed the length-length relationship for Bali sardinella. For another species of sardine group, Sardinella aurita, was held by Bayhan \& Kara (2012). The correlation value (r) for all of the length-length relationship approached 1, which means that the formula was reliable to be used for converting a type of length to the others. In the field, sometimes the tail was broken which inhibit to measure the total length. This formula could be used to overcome the technical things and also the length-length relationship is useful for comparing growth studies (Moutopoulos \& Stergiou 2002).

In the length-weight relationship the values of b (slopes) ranged 2.4-3.5 (Effendie 2002). If $b$-value is outside of this range, it can be conclude that the fish form is not common or different from the fish form in general.

Table 2. Length-weight relationship among Clupeidae family (Asriyana 2015)

\begin{tabular}{lcclc}
\hline \multicolumn{1}{c}{ Species } & $\mathrm{b}$ & Growth pattern & \multicolumn{1}{c}{ Location } & Reference \\
\hline Sardinella longiceps & 3.00 & isometric & Sibolga Bay & 1 \\
Sardinella brasiliensis (larvae) & 2.67 & allometric & Brazilian Continental Shelf & 2 \\
Sardinella aurita & 3.07 & isometric & Mediterania & 3 \\
Harengula clupeola (adult) & 3.85 & allometric & Grand Cull-de-Sac & 4 \\
Opisthonema oglinum (juvenile) & 3.34 & allometric & Grand Cull-de-Sac & 4 \\
Sardinella fimbriata (Male) & 3.03 & isometric & Kendari Bay & 5 \\
Sardinella fimbriata (Female) & 3.04 & isometric & & 5 \\
Sardinella atricauda (Male) & 2.94 & allometric & Kendari Bay & \\
Sardinella atricauda (Female) & 2.52 & allometric & & \\
Sardinella atricauda (Total) & 2.90 & allometric & & \\
\hline
\end{tabular}

1 Tampubolon et al. (2002), 2 Rossi-Wongtchowski et al. (2003), 3 Tsikliras et al. (2005), 4 Vaslet et al. (2008), 5

Asriyana et al. (2010) 
The $\mathrm{b}$ value formed in the length-weight relationship of Bali Sardinella was 3.22, so the growth pattern is expressed as positive allometric. Merta (1992) said that the b value of Bali Sardinella in Bali Strait waters ranged from 2.5 3.5; and Mahrus (1995) concluded that the growth of lemuru fish (S. longiceps) in Alas Strait waters was positive allometric $(b>3)$. Positive allometric means that weight gains faster than the increase in length. The regression results of the length-weight relationship of siro, Sardinella articauda male, female, and combined (male and female) from Kendari Bay waters in Southeast Sulawesi had a negative allometric growth pattern (Table 2), which means that the length growth of siro was faster than its weight (Asriyana 2015).

The length-weight relationship of fish can change through time so that these relationships have a relative nature. $b$-value is possible to change due to environmental factors, such as the condition of the aquatic environment and food availability (Nikolsky 1963, Ricker 1975, Poernomo et al. 2011, Himelda 2013). The fish growth is influenced by internal and external factors. Internal factors include heredity, gender, and age. These factors are difficult to control. External factors such as food availability, water temperature, parasites and diseases are the main factors that influence fish growth (Effendie 2002).

Studies related to the influenced external factors on the fish growth have been carried out. Pangkey (2011) states that lipids (essential fatty acids) are one of the important nutritional of components for the growth of aquaculture biota, especially in the maturation stage of gonads and larvae. Nutrient content of tilapia fish (Oreochromis mossambicus) in Lake University Ma- kassar was higher than in Lake Mawang, but the mineral content was higher in tilapia from the lake Mawang (Syahril et al. 2016).

\section{Conclusion}

Growth pattern of Bali Sardinella (Sardinella Lemuru Bleeker 1853) is a positive allometric. Weight and length Bali Sardinella have a strong relationship; with the $b$ value.

The relationship between total length and standard length; fork length and total length; standard length and fork length of Bali sardinella were $\mathrm{TL}=1.1038 \mathrm{SL}+0.9313 ; \mathrm{TL}=1.0861 \mathrm{SL}$ $+0.2967 ; \mathrm{FL}=1.0068 \mathrm{SL}+0.6936$ respectively.

\section{References}

Asriyana. 2015. Pertumbuhan dan faktor kondisi ikan siro, Sardinella atricauda, Gunther 1868 (Pisces: Clupeidae) di Perairan Teluk Kendari, Sulawesi Tenggara. Jurnal Iktiologi Indonesia, 15 (1): 77-86.

Bayhan B, Kara A, Handzic M (Editor). 2012. Length-length and length-weight relationships of the round sardinella Sardinella aurita Valenciensis, 1847 (Osteichthyes, Clupeidae) from the Aegean Sea. Proceedings of the 3rd International Symposium on Sustainable Development. Sarajevo May 31-June 1 2012. International Burch University. Sarajevo. pp. 110-112.

Beyer JE. 1987. On length-weight relationships. Part I: Computing the mean weight of the fish of a given length class. Fishbyte, 5(1): 11-13.

Bolger T, Connoly PL. 1989. The selection indices for the measurement and analysis of fish condition. Journal of Fish Biology, 17(3): 171-182.

Buchary EA. 2010. In search of viable policy options for responsible use of sardine resources in the Bali Strait, Indonesia. Thesis. University of British Columbia (Vancouver). $383 \mathrm{p}$.

Djamali RA. 2007. Evaluasi keberlanjutan dan optimalisasi pemanfaatan sumberdaya ikan lemuru (Sardinella lemuru Bleeker 1853) di perairan Selat Bali. Dissertation. 
Sekolah Pascasarjana. Institut Pertanian Bogor. Bogor. 154 p.

Effendie IM. 2002. Biologi Perikanan. Yayasan Pustaka Nusatama. Bogor. 163 p.

Froese R \& Pauly D (editor). 2018. Fish Base. World Wide Web electronic publication. www.fishbase.org. version (02/2018).

Gaughan DJ, Mitchell RWD. 2000. The biology and stock assessment of the tropical sardine, Sardinella lemuru of the Midwest Coast of Western Australia. Fisheries Research Report 119. Fisheries Department. Western Australia. 136 p.

Ginanjar M. 2006. Kajian reproduksi ikan lemuru (Sardinella lemuru Blk.) berdasarkan perkembangan gonad dan ukuran ikan dalam penentuan musim pemijahan di perairan pantai timur Pulau Siberut. Thesis. Sekolah Pascasarjana. Institut Pertanian Bogor. Bogor. $56 \mathrm{p}$.

Himelda. 2013. Model keberlanjutan pengelolaan perikanan lemuru (Sardinella lemuru Bleeker 1853) di Selat Bali. Dissertation. Sekolah Pascasarjana. Institut Pertanian Bogor. Bogor. 237 p.

Luceño AJM, Torres MAJ, Tabugo SRM, and Demayo CG. 2014. Describing the body shapes of three populations of Sardinella lemuru (Bleeker, 1853) from Mindanao Island, Philippines using relative warp analysis. International Research Journal of Biological Science, 3(6): 6-17.

Mahrus. 1995. Studi reproduksi ikan lemuru $(S$. lemuru Bleeker 1853) di perairan Selat Alas, Nusa Tenggara Barat. Thesis. Program Pascasarjana. Institut Pertanian Bogor. Bogor. 84 p.

Mahrus, Sumitro SB, Widodo N, Sartimbul A. 2012. The association between genetic variations and omega-3 production on Sardinella lemuru in Lombok Strait. Journal of Agriculture and Veterinary Science, 1(6): 12-16.

Merta IGS. 1992. Dinamika populasi ikan lemuru, Sardinella lemuru Bleeker 1853 (Pisces: Clupeidae) di perairan Selat Bali dan alternatif pengelolaannya. Dissertation. Program Pascasarjana. Institut Pertanian Bogor. Bogor. 201 p.

Moutopoulos DK, Stergiou KI. 2002. Lengthweight and length-length relationships of fish species from the Aegean Sea
(Greece). Journal of Applied Ichthyology, 18(3): 202-203.

Nikolsky GV. 1963. The Ecology of Fishes. Translated from Russian by L. Birkett. Academic Press, London and New York. $352 \mathrm{p}$.

Pangkey H. 2011. Needs of essential fatty acid in marine fish. Journal of Fisheries and Marine Tropical, 7(2): 93-102.

Pedrosa-Gerasmio IR, Agmata AB, Santos MD. 2015. Genetic diversity, population genetic structure, and demographic history of Auxis thazard (Perciformes), Selar crumenophthalmus (Perciformes), Rastrelliger kanagurta (Perciformes), and Sardinella lemuru (Clupeiformes), in Sulu Celebes Sea, inferred by motokondrial DNA sequences. Fisheries Research, 162: 64-74.

Pertami ND, Tampobolon PARP, Rahardjo MF, Sumi A (Editor). 2017. Preliminary study of ichthyofauna in Bali Strait waters. Proceedings of the National Symposium on Fish and Fisheries. Denpasar, January 26 - 28 2017. Udayana University Press. Bali. pp. $257-264$.

Poernomo A, Purwanto, and Ahmadi. 2011. Combating illegal, unreported and unregulated (IUU) fishing to attain food security and alleviate poverty: Initiative of Indonesia. Fish for the People, 9(2): 7985

Prasetyo AP, Purwoko RM. 2016. Inter-specific competition and fishing effect to population dynamic of Bali sardine (Sardinella lemuru). Indonesian Fisheries Research Journal, 22(2): 85-90.

Purwaningsih R, Widjaja S, Partiwi SG. 2011. The effect of marine fish biomass stock reduction to fishers revenue (A case study of Sardinella lemuru fisheries on Bali Strait). IPTEK. The Journal for Technology and Science, 22 (3): 166-176.

Purwaningsih R. 2015. Analysis added value of lemuru fisheries products in Muncar Port, Banyuwangi. Journal of Industrial Engineering Scientific, 14(1): 13-23.

Ricker WE. 1970. IBP Handbook No.3: Methods for assesment of fish production in freshwater. Second printing. International Biological Progaramme. Blackwell Scientic Publications. Oxford and Edinburgh. London. $313 \mathrm{p}$ 
Ricker WE. 1975. Computation and interpretation of biological statistics of fish populations. Bulletin of the Fisheries Research Board of Canada Department of the Environment Fisheries and Marine Service. Ottawa, Canada. 382 pp.

Sartimbul A, Nakata H, Rohadi E, Yusuf B, Kadarisman HP. 2010. Variation in chlorophyll-a concentration and the impact on Sardinella lemuru catches in Bali strait, Indonesia. Progress in Oceanography, 87(1):168-174.

Sikoki FD, Otobotekere AJT. 1999. Fisheries. In: Alagoa EJ (Editor). The Land and People of Baysela State. Central Niger Delta. Port Harcourt. pp. 301-319.

Simbolon D, Wiryawan B, Wahyuningrum PI, and Wahyudi H. 2011. Utilization level and pattern of lemuru fishing season in Bali Strait waters. Bulletin PSP, 19(3): 293-307.

Syahril, Soekendarsi E, and Hasyim Z. 2016. Comparison of nutrient substances of ti- lapia fish Oreochromis mossambicus from Hasanuddin Lake, Makasar University and Mawang Lake, Gowa South Sulawesi. Journal of Makassar Biology, 1(1): 1-7.

Tinungki GM. 2005. Evaluasi model produksi surplus dalam menduga hasil tangkapan maksimum lestari untuk menunjang kebijakan pengelolaan perikanan lemuru di Selat Bali. Dissertation. Sekolah Pascasarjana. Institut Pertanian Bogor. Bogor. $154 \mathrm{p}$.

Willette DA, Santos MD. 2013. Correcting widespread misidentifications of the highly abundant and commercially important sardine species Sardinella lemuru in the Philippines. Journal of Applied Ichthyology, 29(4): 881-885.

Wujdi A, Suwarso, Wudianto. 2012. Relationship of length-weight, condition factors and size structure of lemuru fish (Sardinella lemuru Bleeker 1853) in Bali Strait waters. Escort, 4 (2): 83-89. 
